\title{
MOLECULAR CHARACTERIZATION AND EXPRESSION PATTERN OF A NOVEL CADMIUM RESISTANCE GENE OF TOBACCO
}

\author{
CARACTERIZAÇÃO E PADRÃO DE EXPRESSÃO MOLECULAR DE UM NOVO \\ GENE DE FUMO PARA RESISTÊNCIA AO CÁDMIO
}

\author{
Nian FUZHAO ${ }^{1}$; Zhao LEIFENG ${ }^{1}$ \\ 1. College of Tobacco Science, Yunnan Agricultural University, Kunming 650201, China. zhleifeng@163.com
}

\begin{abstract}
Cadmium $(\mathrm{Cd})$ of tobacco is a pollutant that is extremely toxic to the health of humans. Protein plant cadmium resistance 8 gene has been characterized to increase the plant Cd resistance. In present experiment, the complete mRNA sequence of tobacco protein plant cadmium resistance 8 gene was amplified using the rapid amplification of cDNA ends methods. The full-length tobacco protein plant cadmium resistance 8 gene mRNA was $887 \mathrm{bp}$ containing an $555 \mathrm{bp}$ open reading frame, which encodes a protein of 184 amino acids. BLAST analysis revealed that tobacco protein plant cadmium resistance 8 protein shares high homology with the protein plant cadmium resistance 8 of potato $(81 \%)$, Lycopersicon esculentum (80\%), Eutrema salsugineum (60\%), Capsella rubella (58\%) and thale cress (57\%). Results also showed that tobacco protein plant cadmium resistance 8 gene has a closer genetic relationship with the protein plant cadmium resistance 8 gene of Lycopersicon esculentum. The expression profile was studied and the results indicated that tobacco protein plant cadmium resistance 8 gene was highly expressed in root, moderately expressed in stem, and hardly expressed in flower and leaf. These results established the primary foundation of utilizing tobacco protein plant cadmium resistance 8 gene to decrease the cadmium content of tobacco and benefit the health of humans in the future.
\end{abstract}

KEYWORDS: Tobacco. Gene. Protein plant cadmium resistance 8. Expression pattern.

\section{INTRODUCTION}

Cadmium $(\mathrm{Cd})$ of tobacco is a pollutant that is extremely toxic to the health of humans. Cd has caused neurotoxicologic and behavioral changes in both humans and experimental animal studies (Liu et al., 2013; Counter et al., 2009). Cd exposure may be implicated in some neurological disorders including hyperactivity and increased aggressiveness in humans (Liu et al., 2013; Matés et al., 2010). In the case of coronary risk with metal levels, Cd may be more important for females (Liu et al., 2013; Olsen et al., 2012). Cd was reported to damage bone microstructures (Liu et al., 2013; Chen et al., 2011) and can negatively influence growth in newborns. Several studies have reported an inverse relationship between anthropometric measurements of the newborn and the placental or umbilical cord Cd levels (Liu et al., 2013; Llanos et al., 2009; Ronco et al., 2009). Cd exposure exerts inhibitory effects on testicular steroidogenesis(Liu et al., 2013; Pillai et al., 2012).

Recent researches have proved that a lot of genes, including protein plant cadmium resistance 8 , can increase the plant $\mathrm{Cd}$ resistance (Thomine et al., 2000; Song et al., 2004; Ishikawa et al., 2012). Protein plant cadmium resistance 8 gene has been identified from many plants such as thale cress, tomato and potato. Until today, the tobacco protein plant cadmium resistance 8 gene has not been reported yet.
In the present work, we isolated the fulllength mRNA sequence of this tobacco gene, subsequently performed some necessary sequence analysis and tissue expression analysis for this gene. These will establish the primary foundation of utilizing tobacco protein plant cadmium resistance 8 gene to decrease the cadmium content of tobacco and benefit the health of humans in the future.

\section{MATERIAL AND METHODS}

\section{Samples collection, RNA extraction and first- strand cDNA synthesis}

Tobacco plants (Chinese local variety Yunyan 87) were grown in a naturally lit glasshouse with normal irrigation and fertilization. The tissues including leave, stem, root and flower were harvested, immediately frozen in liquid nitrogen and stored at $-80^{\circ} \mathrm{C}$. Total RNA extraction and firststrand cDNA synthesis for these tissue samples were performed as the methods describe by Liu (2009).

\section{5'and 3'-RACE \\ 5'- and 3'-RACE were performed as the instructions of SMART $^{\mathrm{TM}}$ RACE CDNA Amplification Kit. For the tobacco protein plant cadmium resistance 8 gene, the gene specific primers (GSPs) were designed based on one tobacco EST sequence: EH623456. 5'-RACE GSP: 5'- GCCCATTATCCATTGAGAGCAAACA-3' 3'-}


RACE

GSP:

$5^{\prime}-$ GCCTGCTGTTTGCTCTCAATGGATA-3' .

RACE touchdown PCRs were carried out with 5 cycles of $94^{\circ} \mathrm{C} 30 \mathrm{sec}$ and $72{ }^{\circ} \mathrm{C} 3 \mathrm{~min}$, followed by 5 cycles of $94^{\circ} \mathrm{C} 30 \mathrm{sec}, 70^{\circ} \mathrm{C} 30 \mathrm{sec}$ and $72{ }^{\circ} \mathrm{C} 3 \mathrm{~min}$, finally with 25 cycles of $94^{\circ} \mathrm{C} 30$ sec, $66^{\circ} \mathrm{C} 30 \mathrm{sec}, 72^{\circ} \mathrm{C} 3 \mathrm{~min}$ to terminate reaction. These RACE PCR products were then cloned into PMD18-T vector (TaKaRa, China) and sequenced bidirectionally with the commercial fluorometric method.

\section{for tissue expression profile analysis \\ Quantitative real time PCR (qRT-PCR) \\ qRT-PCR for evaluating the level of mRNA for protein plant cadmium resistance 8gene was}

FUZHAO, N.; LEIFENG, Z.

performed by the ABI Prism 7300 Sequence Detection Systems (Applied Biosystems, Foster City, CA, USA). 25 $\mu$ l reaction volume of PCR reaction contained $1 \mu 1$ SYBR Green real-time PCR Master Mix, 100 ng cDNA template and $200 \mathrm{nM}$ each primer. Conditions for real-time PCR were: an initial denaturation at $95^{\circ} \mathrm{C}$ for $3 \mathrm{~min}, 40$ cycles of $95{ }^{\circ} \mathrm{C}$ for $15 \mathrm{~s}$, optimal annealing temperature for each specific primer for $15 \mathrm{~s}$ (Table 1 ), $72^{\circ} \mathrm{C}$ for 20 s. The gene relative expression levels were quantified relative to the expression of the reference gene, actin (GenBank Accession No. GQ339768), by employing the $2^{-\Delta \Delta \mathrm{Ct}}$ value model (Livak et al., 2001).

Table 1. qRT-PCR primers for tobacco protein plant cadmium resistance 8 and actin genes

\begin{tabular}{|c|c|c|c|}
\hline Gene & Primer sequence & $\begin{array}{l}\mathrm{Tal} \\
{ }^{\circ} \mathrm{C}\end{array}$ & Length/(bp) \\
\hline & Forward & & \\
\hline protein plant cadmium & TGGATACAATGGGAAGAG -3' & & \\
\hline resistance 8 & $\begin{array}{l}\text { Reverse: 5' - ATGGACAGAATATGTGGG } \\
-3 \text {, }\end{array}$ & 52 & 420 \\
\hline Actin & $\begin{array}{l}\text { Forward :5'- } \\
\text { CCATTCTTCGTTTGGACCTT -3' } \\
\text { Reverse: 5' - TTCTGGGCAACGGAACCT- } \\
\text { 3' }\end{array}$ & 56 & 257 \\
\hline
\end{tabular}

\section{Sequence analysis}

Gene prediction of cDNA sequence was performed by GenScan software (http://genes.mit.edu/GENSCAN.html). Theoretical isoelectric point $(\mathrm{pI})$ and molecular weight $(\mathrm{Mw})$ of the deduced protein was computed using the Compute $\quad \mathrm{pI} / \mathrm{Mw}$ Tool (http://www.expasy.org/tools/pi_tool.html). Protein analysis were carried out using the BLAST tool at the National Center for Biotechnology Information (NCBI) server (http://www.ncbi.nlm.nih.gov/BLAST) and the Clustalw software (http://www.ebi.ac.uk/clustalw).

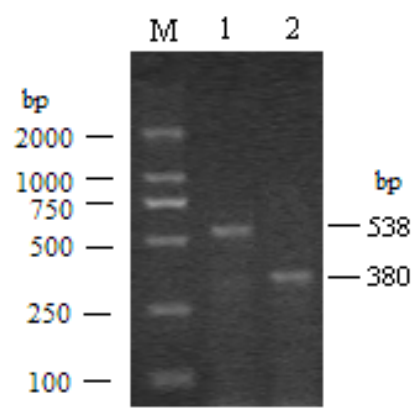

Figure1. RACE results for tobacco protein plant cadmium resistance 8 gene. M DL2000 DNA markers; 1, 3'-

\section{RESULTS}

\section{RACE results for tobacco protein plant cadmium resistance 8 gene}

For tobacco protein plant cadmium resistance 8 gene, through 5'-RACE, one PCR product of 380-bp was obtained. The 3'-RACE product was 538-bp in length. These products were then cloned to $\mathrm{T}$-vector and sequenced. Taken together, a 887-bp cDNA sequence was finally obtained (Figure 1).

\footnotetext{
RACE product for tobacco protein plant cadmium resistance 8 gene; 2 , 5'-RACE product for tobacco protein plant cadmium resistance 8 gene
} 


\section{Sequence analysis}

BLAST analysis of this cDNA sequence revealed that this sequence was not homologous to any of the known tobacco gene and it was then deposited into the Genbank database (Accession number: KJ159912).

Sequence prediction was carried out and results showed that this 887-bp cDNA sequence represents
FUZHAO, N.; LEIFENG, Z.

one single gene which encodes 184 amino acids(Figure 2). The theoretical isoelectric point (pI) and molecular weight $(\mathrm{Mw})$ of this deduced protein was also computed. The pI of tobacco protein plant cadmium resistance 8 is 5.29. The molecular weight is 20371.27 .

AATTTTCTTCATCCACTTGAGGTGTATACGTAGGTGTAAAATTTTTGGATACAATGGGAAGAGTTG $\begin{array}{llllllllllllllllllllllllll}\text { A } & \text { A } & G & \text { A } & \text { A } & \text { A } & \text { A } & \text { T } & \text { A } & \text { A } & \text { T } & G & \text { A } & \text { A } & \text { A } & \text { T } & \text { A } & G & \text { A } & \text { A } & \text { A } & \text { C } & \text { T } & \text { C } & \text { C } & \text { T }\end{array}$ AAACCAGGTGAGAGTGGTGAACCAGTTGCCTCACAGCCTCCTCCACAGTACCAAGGAGTAAAGG

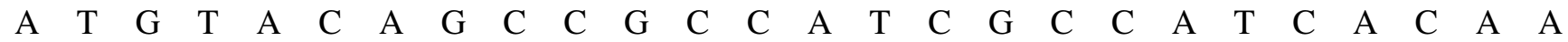
$\begin{array}{lllllllllllllllllllllllllllllll} & \mathrm{K} & \mathrm{P} & G & \mathrm{E} & \mathrm{S} & G & \mathrm{E} & \mathrm{P} & \mathrm{V} & \mathrm{A} & \mathrm{S} & \mathrm{Q} & \mathrm{P} & \mathrm{P} & \mathrm{P} & \mathrm{Q} & \mathrm{Y} & \mathrm{Q} & \mathrm{G} & \mathrm{V} & \mathrm{K} & \mathrm{D} & \mathrm{V} & \mathrm{Q} & \mathrm{P} & \mathrm{P} & \mathrm{S} & \mathrm{P} & \mathrm{S} & \mathrm{Q}\end{array}$ CCAATTGGAGCTCCCTGGAGCACTGGCTTATTTGATTGTCATTTGAACCAGATTAATGCTGTTATG

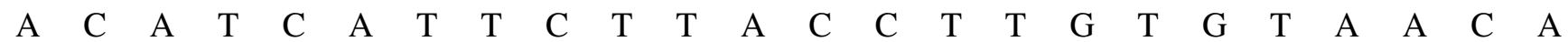

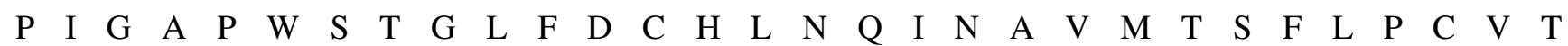
TTCGGACAGATAGCAGAAGTCCTCGATGCAGGAGAAATGACATGTCCTTTGGGGACTTTCATATA $\begin{array}{lllllllllllllllllllllllll}\mathrm{C} & \mathrm{T} & \mathrm{T} & \mathrm{G} & \mathrm{C} & \mathrm{T} & \mathrm{G} & \mathrm{A} & \mathrm{T} & \mathrm{G} & \mathrm{A} & \mathrm{T} & \mathrm{G} & \mathrm{C} & \mathrm{C} & \mathrm{T} & \mathrm{G} & \mathrm{C} & \mathrm{T} & \mathrm{G} & \mathrm{T} & \mathrm{T} & \mathrm{T} & \mathrm{G} & \mathrm{C}\end{array}$

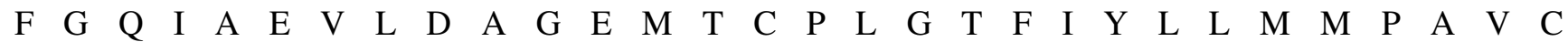
TCTCAATGGATAATGGGCTCTAAGTATAGAACTAAGCTGAGACAGAAATATAATCTTGTCGAAGC $\begin{array}{lllllllllllllllllllllllll}\mathrm{T} & \mathrm{C} & \mathrm{C} & \mathrm{T} & \mathrm{T} & \mathrm{A} & \mathrm{T} & \mathrm{T} & \mathrm{C} & \mathrm{A} & \mathrm{G} & \mathrm{A} & \mathrm{C} & \mathrm{A} & \mathrm{T} & \mathrm{A} & \mathrm{G} & \mathrm{T} & \mathrm{T} & \mathrm{T} & \mathrm{C} & \mathrm{C} & \mathrm{C} & \mathrm{A} & \mathrm{C}\end{array}$ $\begin{array}{llllllllllllllllllllllllllllll}S & Q & \text { W } & \text { I } & M & G & S & K & Y & R & T & K & L & R & Q & K & Y & N & L & V & E & A & P & Y & S & D & I & V & S & H\end{array}$ ATATTCTGTCCATGTTGCTCTCTTTGTCAAGAGTTCAGAGAACTTCAACACAGGGGACTTGATCCT $\begin{array}{llllllllllllllllllllllll}G & C & T & C & T & A & G & G & A & T & G & G & A & A & T & G & G & T & A & T & A & G & T & T\end{array}$

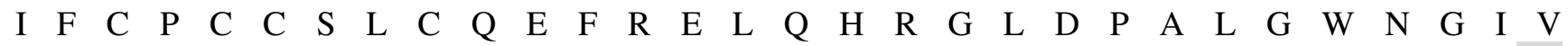
GCTCAGCAGCATTATGGGAACCAACAAGTGAATCAAGCTCCCCAAGTACAATCCATGTCTAAGTA $\begin{array}{lllllllllllllllllllllllllll}\mathrm{A} & \mathrm{A} & \mathrm{A} & \mathrm{T} & \mathrm{T} & \mathrm{C} & \mathrm{A} & \mathrm{A} & \mathrm{G} & \mathrm{A} & \mathrm{T} & \mathrm{T} & \mathrm{C} & \mathrm{T} & \mathrm{G} & \mathrm{A} & \mathrm{T} & \mathrm{T} & \mathrm{C} & \mathrm{T} & \mathrm{T} & \mathrm{T} & \mathrm{A} & \mathrm{T} & \mathrm{T} & \mathrm{T} & \mathrm{G}\end{array}$ $\begin{array}{llllllllllllllllllllll}\mathrm{A} & \mathrm{Q} & \mathrm{Q} & \mathrm{H} & \mathrm{Y} & \mathrm{G} & \mathrm{N} & \mathrm{Q} & \mathrm{Q} & \mathrm{V} & \mathrm{N} & \mathrm{Q} & \mathrm{A} & \mathrm{P} & \mathrm{Q} & \mathrm{V} & \mathrm{Q} & \mathrm{S} & \mathrm{M} & \mathrm{S} & \mathrm{K} & *\end{array}$ TTTGAGTTAAGGTTGTAATATGTTACATGTGTTTTGACACACCCAGATTCTGTTCATGTTGTAGCCT TTATTATTTATTCCAACAATCTTGTTGGCAGTGTTGATTGTTGTACTATGTTTCTAGAACTCTATTTT TGGGAGTTACATACTTCCGCGTATATGAAAATTGAGTTTGCAATGATCTAATGAAGTCTTGGCATC AATTATTAATTGGGCAGTTCGATAAAAAAAAAAAAAAAAAAAAAAAAAAAAA

\section{Figure 2. The complete mRNA of tobacco protein plant cadmium resistance 8 gene and its encoding amino acids. *indicates the stop codon.}

Further BLAST analysis of this protein revealed that tobacco protein plant cadmium resistance 8 shares high homology with the protein plant cadmium resistance 8 of potato(Accession number: XP_006356149, 81\%), Lycopersicon esculentum (Accession number: XP_004241740, 80\%), Eutrema salsugineum (Accession number: XP_006392946, 60\%), Capsella rubella (Accession number: XP_006305669, 58\%) and thale cress (Accession number: AAM62872, 57\%) (Figure 3).

Based on the results of the alignment of different protein plant cadmium resistance 8 proteins, a phylogenetic tree was constructed using the ClustalW software, as shown in Figure 4. Phylogenetic analysis revealed that the tobacco protein plant cadmium resistance 8 gene has a closer genetic relationship with that of Lycopersicon esculentum

\section{Tissue expression profile}

Tissue expression profile analysis was carried out and results revealed that the tobacco protein plant cadmium resistance 8 gene was highly expressed in root, moderately expressed in stem, and hardly expressed in flower and leaf (Figure 5). 


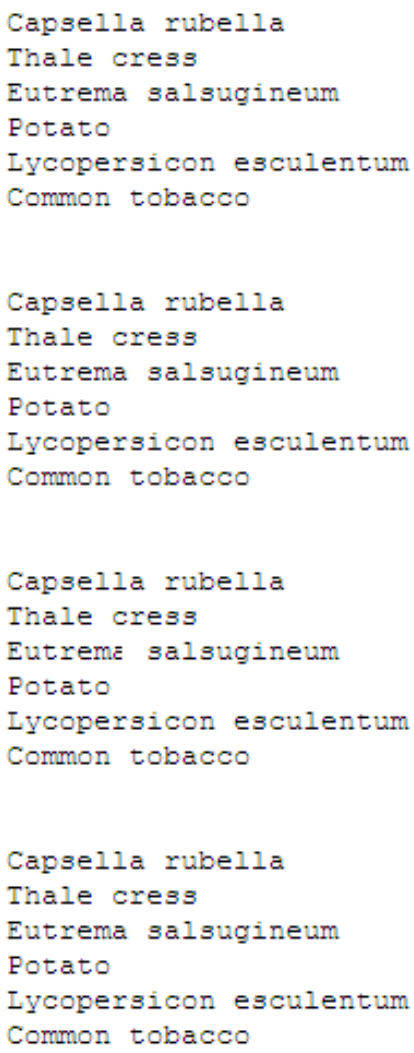

MGRVT-EHEENPNNGT PVQQRGT PNQQTGVPASQFAP PNYQQANVNLSIG MGRVTT PSEEDSNNGL PVQQPGT PNQRTRVPVSQFA.PPNYQQANVNLSVG MGRVTT PPEENPKNGFPAQQTGTP--------SQFAPPNYHQANVKLSVG MGRVEANNEEETSQAESGTEPAASQPQ-----QLQGVQGVYQSPPHLTIG MGRVEANNEGETSQAESGTEPAISQPQ-----QEQGVQSVYQSPSHLTIG MGRVEENNE IETPKPGESGE PVASQPPP----QYQGVKDVQPPSPSQPIG $* * * * \quad * \quad . \quad: \quad: \quad . \quad . \quad . \quad . \quad . \quad .: *$

RPWST GLFDCHEDQANALMTT IAPCVT FGQITEVVDEGDMTCPLGT FMYL RPWSTGLFDCQADQANAVLTT IVPCVT FGQIAEVMDE GEMTCPLGT FMYL SPWRTGLFDCQEDQTNAVMTSILPCVTFGQIAEVVDEGEMTCPLGSFIYL APWSTGLFDCHLDQTNAVMTAFLPCVTFGQIAEVLDAGQMTCPLGTFIYM APWSTGLFDCHLDQTNAVMTAFLPCVTFGQIAEVLDAGQMTCPLGTFIYM APWSTGLFDCHLNQINAVMTSFL PCVTFGQIAEVLDAGEMTCPLGTFIYL $* * * * * * * *:: * * *:: *:: * * * * \pi * * *: * *: * *: * * * * * *: *: *:$

LMMPALCSQWVMGSKYREKMRRKFNLVEAPYSDCASHLICPCCALCQEYR LMMPALCSHWVMGSKYREKMRRKFNLVEAPYSDCASHVLCPCCSLCQEYR LMMPALCSQWVMGSKYREKIRRKFNLVEAPYSDCITHVFCSCCALCQEYR LMMPAICSQWIMGSKYRTQLRQRYNLVEAPYSDMISHMFCPCCSICQEFR LMMPAVCSQWIMGSKYRTQLRQRYNLVEAPYSDMISHMFCPCCSLCQEFR LMMPAVCSQWIMGSKYRTKLRQKYNLVEAPYSDIVSHIFCPCCSLCQEFR

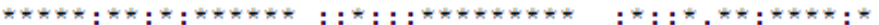

ELKIRNLDPSLGWNGILAQG--QYGSEAPTFAPTNQYMSK ELKIRNLDPSLGWNGILAQGQGQYESEAPSFAPTNQYMSK ELKARNLDPSLGWNGILAQRQGHYESEAPSSAPPNQYMSK ELRNRGLDPALGWNGIVAQQ--HYGNQQVNQAPQVQSMSK ELRNRGLDPALGWNGIVAQR--HYGNQQVNQAPQVQSMSM ELQHRGLDPALGWNGIVAQQ--HYGNQQVNQAPQVQSMSK $* *: * * * *: * * * * * * ; * *: *:, * * * * *$

Figure 3. The alignment of the proteins encoded by tobacco and other protein plant cadmium resistance 8 genes

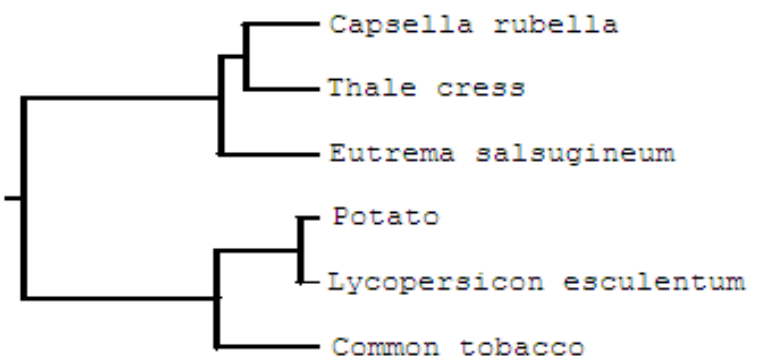

Figure4. The phylogenetic tree for six kinds of protein plant cadmium resistance 8 genes

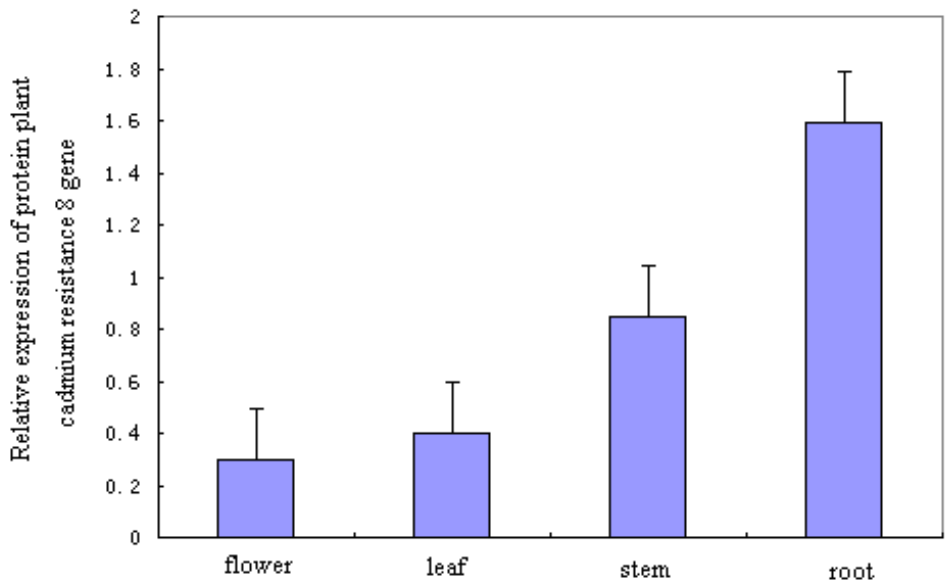

Figure 5. Expression analysis of protein plant cadmium resistance 8 gene in various tobacco tissues 


\section{DISCUSSION}

Comparative genomics research has revealed that virtually all (99\%) of the proteincoding genes in humans align with homologs in mouse, and over $80 \%$ are clear 1:1 orthologs for human and mouse both belong to mammalian (Hardison, 2003; Liu,2009). This extensive conservation in protein-coding regions implied that this conservation of protein-coding sequences may be expected in tobacco and other plants of solanaceae. From the sequence analysis of protein plant cadmium resistance 8 genes, it can be seen that the coding sequences of protein plant cadmium resistance 8 genes were highly conserved in three solanaceae plants-tobacco, potato and Lycopersicon esculentum.

The phylogenetic tree analysis revealed that the tobacco protein plant cadmium resistance 8 gene has a closer genetic relationship with that of Lycopersicon esculentum. This implied that we can use Lycopersicon esculentum as model organism to study the tobacco protein plant cadmium resistance 8 gene or use tobacco as model organism to study
FUZHAO, N.; LEIFENG, Z.

the Lycopersicon esculentum protein plant cadmium resistance 8 gene.

From the tissue distribution analysis in our experiment it can be seen that protein plant cadmium resistance 8 gene was highly expressed in root. For protein plant cadmium resistance 8 can increase the plant $\mathrm{Cd}$ resistance (Thomine et al., 2000; Song et al., 2004; Ishikawa et al., 2012), the suitable explanation for this is that tobacco cadmium resistance is mainly existed in root.

In conclusion, we first isolated the tobacco protein plant cadmium resistance 8 gene and performed necessary sequence analysis and tissue expression profile analysis. These will establish the primary foundation of utilizing tobacco protein plant cadmium resistance 8 gene to decrease the cadmium content of tobacco and benefit the health of humans in the future.

\section{ACKNOWLEDGMENTS}

This work was supported by grants from the Science and Technology Development Plan of Yunnan Provincial Tobacco Monopoly Administration (Corporation) (2013YN05).

RESUMO: Cádmio (Cd) oriundo do fumo é um poluente que é extremamente tóxico a saúde humana. Um gene encontrado na planta de fumo que codifica uma proteína para resistência (gene 8) tem sido caracterizado para aumentar a resistência do fumo na absorção do elemento Cádmio (Cd).No experimento realizado a sequiência do mRNA de fumo que codifica uma proteína foi amplificada usando métodos de amplificação de CDNAs. A proteína completa codificada pelo gene 8 apresenta um mRNA com 887 pb com uma fita de leitura de $555 \mathrm{pb}$, a qual codifica 184 aminoácidos. A análise de BLAST demonstrou uma homologia de $81 \%$ com o gene 8 da batateira, de $80 \%$ com o tomateiro (Lycopersicon esculentum), $60 \%$ para Eutrema salsugineum, $58 \%$ para Capsella rubella e $57 \%$ para o agrião. A proteína expressada pelo gene 8 para resistência do fumo a absorção do Cádmio também apresenta um forte relacionamento genético com a proteína expressa pelo gene 8 do tomateiro (Lycopersicon esculentum). Os perfis da expressão protéica para a proteína oriunda do gene 8 do fumo foi de grande magnitude em raiz, moderadamente expressa no caule e de difícil expressão nas flores e nas folhas. Estes resultados obtidos fundamentam o uso deste gene 8 de fumo para resistência ao Cádmio com o propósito de reduzir o teor de cádmio na planta de fumo e com reflexos benéficos para a saúde humana no futuro.

PALAVRAS-CHAVE: Fumo. Gene. Proteína 8 para resistência ao Cádmio. Padrão de expressão.

\section{REFERENCES}

CHEN, X.; ZHU, G.; SHAO, C.; JIN, T.; TAN, M.; GU, S. et al. Effects of cadmium on bone microstructure and erum tartrate-resistant acid phosphatase 5b in male rates. Exp Biol Med, Maywood, v. 236, n. 11, p. 12981305, 2011. http://dx.doi.org/10.1258/ebm.2011.011104

COUNTER, S. A; BUCHANAN, L. H.; ORTEGA, F. Neurocognitive screening of lead exposed Andean adolescents and young adults. J Toxico Environ Health A, v. 72, n. 10, p. 625-632, 2009. http://dx.doi.org/10.1080/15287390902769410 
HARDISON, R. C. (2003) Comparative genomics. PLoS Biol 1:E58.

http://dx.doi.org/10.1371/journal.pbio.0000058

ISHIKAWA, S.; ISHIMARU, Y.; IGURA, M.; KURAMATA, M.; ABE, T.; SENOURA, T.; HASE, Y.; ARAO, T.; NISHIZAWA, N. K.; NAKANISHI, H. Ion-beam irradiation, gene identification, and markerassisted breeding in the development of low-cadmium rice. Proc Natl Acad Sci U S A, v. 109, n. 47, p. 1916671, nov. 2012. http://dx.doi.org/10.1073/pnas.1211132109

LIU, G. Y. Isolation, sequence identification and tissue expression profile of two novel soybean (glycine max) genes-vestitone reductase and chalcone reductase. Mol Biol Rep. v. 36, n. 7, p. 1991-4, Sep. 2009.

http://dx.doi.org/10.1007/s11033-008-9409-y

LIU, K.; GU, P.; CHEN, W.; SHI, J.; SHI, C.; XIA, L. Effect of Pregnancy on the Levels of Blood Cadmium and Lead: analysis of 2006-2011 Nanjing Maternity and Child Health Care Hospital Survey Data. Iran J Public Health, v. 42, n. 7, p. 691-9, Jul. 2013.

LIVAK, K. J, SCHMITTGEN, T. D. Analysis of relative gene expression data using real-time quantitative PCR and the 2(-Delta Delta C(T)) Method. Methods, v. 25, n. 4, p. 402-8, Dec 2001.

http://dx.doi.org/10.1006/meth.2001.1262

LLANOS, M. N; RONCO, A. M. Fetal growth restriction is related to placental levels of cadmium, lead and arsenic but not with antioxidant activities. Reprod Toxicol, v. 27, n. 1, p. 88-92, 2009.

http://dx.doi.org/10.1016/j.reprotox.2008.11.057

MATÉS, J. M.; SEGURA, J. A.; ALONSO, F. J.; MÁRQUEZ, J. Role of dioxins and heavy metals in cancer and neurological diseases by ROS-mediated mechanisms. Free Radic Biol Med., v. 49, n. 9, p. 1328-134, 12010.

OLSEN, L.; LIND, P. M.; LIND, L. Gender differences for associations between circulating levels of metals and coronary risk in he elderly. Int JHyg Environ Health, v. 215, n. 3, p. 411-417, 2012.

http://dx.doi.org/10.1016/j.ijheh.2011.11.004

PILLAI, P.; PANDYA, C.; BHATT, N.; GUPTA, S. Biochemical and reproductive effects of gestational/lactational exposure to lead and cadmium with respect to testicular steroidogeneis, antioxidant system, endogenous sex steroid and cauda epididymal functions. Andrologia, v. 44, n. 2, p. 92-101, 2012. http://dx.doi.org/10.1111/j.1439-0272.2010.01109.x

RONCO, A. M.; URRUTIA, M.; MONTENEGRO, M.; LLANOS, M. Cadmium exposure during pregnancy reduces birth weight and increases maternal and foetal glucocorticoids. Toxicol Lett, v. 188, n. 3, p. 186-191, 2009. http://dx.doi.org/10.1016/j.toxlet.2009.04.008

SONG, W. Y.; MARTINOIA, E.; LEE, J.; KIM, D.; KIM, D. Y.; VOGT, E.; SHIM, D.; CHOI, K. S.; HWANG, I.; LEE, Y. A novel family of cys-rich membrane proteins mediates cadmium resistance in Arabidopsis. Plant Physiol., v. 135, n. 2, p. 1027-39. Jun. 2004. http://dx.doi.org/10.1104/pp.103.037739

THOMINE, S.; WANG, R.; WARD, J. M.; CRAWFORD, N. M. SCHROEDER, J. I. Cadmium and iron transport by members of a plant metal transporter family in Arabidopsis with homology to Nramp genes. Proc Natl Acad Sci U S A., v. 97, n. 9, 4991-6. Apr. 2000 . http://dx.doi.org/10.1073/pnas.97.9.4991 